Article

\title{
Remodeling of Human Osteochondral Defects via rAAV-Mediated Co-Overexpression of TGF- $\beta$ and IGF-I from Implanted Human Bone Marrow-Derived Mesenchymal Stromal Cells
}

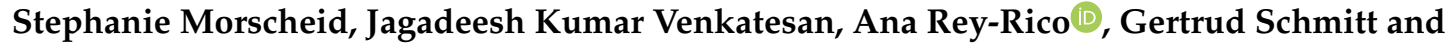 \\ Magali Cucchiarini * (D) \\ Center of Experimental Orthopaedics, Saarland University Medical Center and Saarland University, \\ 66421 Homburg/Saar, Germany \\ * Correspondence: mmcucchiarini@hotmail.com; Tel.: +49-6841162-4987; Fax: +49-6841162-4988
}

Received: 3 August 2019; Accepted: 26 August 2019; Published: 28 August 2019

\begin{abstract}
The application of chondrogenic gene sequences to human bone marrow-derived mesenchymal stromal cells (hMSCs) is an attractive strategy to activate the reparative activities of these cells as a means to enhance the processes of cartilage repair using indirect cell transplantation procedures that may improve the repopulation of cartilage lesions. In the present study, we examined the feasibility of co-delivering the highly competent transforming growth factor beta (TGF- $\beta$ ) with the insulin-like growth factor I (IGF-I) in hMSCs via recombinant adeno-associated virus (rAAV) vector-mediated gene transfer prior to implantation in a human model of osteochondral defect (OCD) ex vivo that provides a microenvironment similar to that of focal cartilage lesions. The successful co-overexpression of rAAV TGF- $\beta /$ IGF-I in implanted hMSCs promoted the durable remodeling of tissue injury in human OCDs over a prolonged period of time (21 days) relative to individual gene transfer and the control (reporter lacZ gene) treatment, with enhanced levels of cell proliferation and matrix deposition (proteoglycans, type-II collagen) both in the lesions and at a distance, while hypertrophic, osteogenic, and catabolic processes could be advantageously delayed. These findings demonstrate the value of indirect, progenitor cell-based combined rAAV gene therapy to treat human focal cartilage defects in a natural environment as a basis for future clinical applications.
\end{abstract}

Keywords: osteochondral defect repair; hMSCs; rAAV vectors; TGF- $\beta$; IGF-I

\section{Introduction}

Focal articular cartilage lesions remain a particularly challenging clinical problem in orthopaedics due to the failure of the articular chondrocytes, the only cell population present in this highly specialized, avascular tissue, to fully provide self-repair activities in sites of cartilage injury [1-4]. Equally critical, none of the surgical options currently employed in orthopaedic surgery to mobilize or even supply chondroregenerative progenitor cells, like those from the subchondral bone marrow (microfracture, pridie drilling, stromal cell transplantation), can reliably support the strict reproduction of the original hyaline cartilage in such lesions with a typical proteoglycan- and type-II collagen-based extracellular matrix (ECM) [1-7]. Instead, a fibrocartilaginous repair tissue mostly composed of type-I collagen is generated in sites of cartilage injury, without the proper mechanical integrity that would allow to withstand mechanical loads over time, and that may progress towards irreversible, degenerative osteoarthritis [1-4].

Strategies that aim to activate the chondroreparative properties of progenitor cells prior to reimplantation in sites of cartilage damage may provide strong tools to overcome these hurdles, 
like approaches using gene therapy procedures that support the specific and long-term targeting of cellular and biological pathways involved in cartilage repair [8,9]. In this regard, vectors derived from the human adeno-associated virus (AAV) vector are particularly well suited to achieve these goals from a translational perspective [10], as recombinant AAV (rAAV) constructs can safely and durably transduce bone marrow-derived mesenchymal stromal cells (MSCs) at very high efficiencies (about 100\% for several weeks) [11-17]. While the rAAV-mediated transduction of MSCs from human patients (hMSCs) has been attempted in a number of trials in vitro by delivering chondrotherapeutic genes coding for the basic fibroblast growth factor (FGF-2) [13], transforming growth factor beta 1 (TGF- $\beta 1$ ) [11,15], insulin-like growth factor I (IGF-I) [16], sex-determining region Y-type high-mobility group box 9 transcription factor (SOX9) [14,17], little is known on the benefits of rAAV for the application of genetically modified hMSCs in human focal cartilage defects in a native microenvironment.

In the present study, we focused on co-delivering TGF- $\beta$ and IGF-I, two potent factors supporting cartilage repair, in hMSCs via $\mathrm{rAAV}$ as improved cell regenerative platforms capable of enhancing the repair activities in a human osteochondral defect (OCD) model system ex vivo, and, in light of our previous work in vitro, showing the feasibility of co-applying these two candidates in settings aiming at directly rejuvenating resident MSCs within a lesion [18]. For the first time, and to our best knowledge, the current work demonstrates that the simultaneous overexpression of TGF- $\beta$ and IGF-I can be effectively achieved in rAAV-targeted hMSCs implanted within human OCDs, promoting the sustained remodeling of the injured human articular cartilage (cell proliferation, hyaline ECM deposition) over a prolonged period of 21 days while containing unwanted hypertrophic, osteogenic, and catabolic processes relative to independent gene treatments and control condition (reporter lac $Z$ gene transfer). These findings show the value of using combined cell- and gene-based therapy via rAAV as a significant means to enhance human cartilage repair in environmental conditions closely resembling those in patients in vivo.

\section{Experimental Section}

\subsection{Study Design}

Human bone marrow-derived MSCs were prepared as high-density aggregates in defined chondrogenic medium and subsequently transduced with the various rAAV vectors (total MOI $=8$ ) as candidate combined rAAV-hTGF- $\beta /$ rAAV-hIGF-I (TGF- $\beta /$ IGF-I; $40 \mu$ L each vector/aggregate) versus independent rAAV-hTGF- $\beta$ (TGF- $\beta /$ lacZ) or rAAV-hIGF-I (IGF-I/lacZ) gene transfer $(40 \mu \mathrm{L}$ each vector/aggregate) or absence of therapeutic gene (reporter $\mathrm{rAAV}-$ lac $Z$ vector, i.e., lac $Z$ condition; $80 \mu \mathrm{L}$ vector/aggregate). Aggregates were then implanted after $24 \mathrm{~h}$ in experimentally created human osteochondral defects (OCDs; 1 aggregate/OCD) in a patient-match manner when both samples were available that were maintained in defined chondrogenic medium for 21 days [5] to evaluate transgene expression and to establish biochemical assays, immunohistochemical and histological analyses, and real-time RT-PCR analyses (Figure 1).

\subsection{Reagents}

All reagents were purchased from Sigma, Munich (Germany) unless otherwise indicated. The dimethylmethylene blue dye (DMMB) was from Serva, Heidelberg (Germany). The anti-TGF- $\beta$ (V) antibody was purchased at Santa Cruz Biotechnology (Heidelberg, Germany), the anti-IGF-I (AF-291-NA) at R\&D Systems (Wiesbaden, Germany), the anti-type-II collagen (II-II6B3) antibody at NIH Hybridome Bank (university of Iowa, Ames, IA, USA), the anti-type-I collagen (AF-5610) antibody at Acris Antibodies, Hiddenhausen (Germany), and the anti-type- $X$ collagen (COL10) antibody at Sigma. Biotinylated secondary antibodies and $A B C$ reagent were from Vector Laboratories Alexis Deutschland, Grünberg (Germany). The TGF- $\beta$ and IGF-I Quantikine ELISAs were purchased at R\&D Systems and the AAVanced Concentration Reagent at System Bioscience (Heidelberg, Germany). 


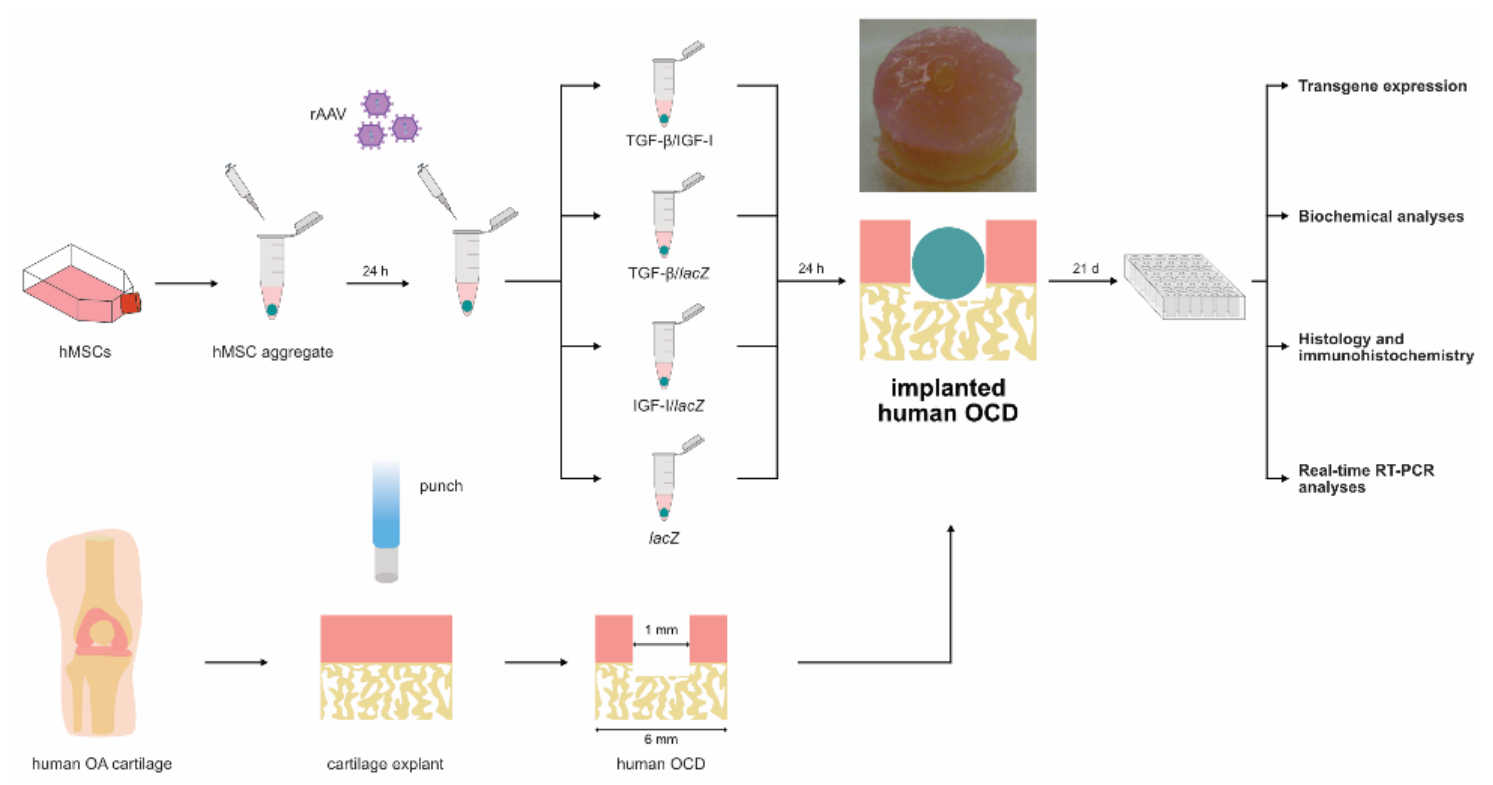

Figure 1. Study design. Human bone marrow-derived mesenchymal stromal cells MSCs were prepared as high-density aggregates $\left(2 \times 10^{5}\right.$ cells/aggregate $)$ in defined chondrogenic medium overnight, transduced with the various rAAV shuttles (TGF- $\beta /$ IGF-I, TGF- $\beta /$ lacZ, IGF-I/lacZ: $40 \mu \mathrm{L}$ each vector/aggregate; lacZ: $80 \mu \mathrm{L}$ vector/aggregate), and directly applied to human osteochondral defects (OCDs; 6-mm diameter) for further culture in defined chondrogenic medium for 21 days when the OCDs were processed to monitor transgene expression and for biochemical, immunohistochemical/histological, and real-time RT-PCR.

\subsection{Cell and Osteochondral Defect Cultures}

Bone marrow aspirates were collected from the distal femurs of patients undergoing total knee arthroplasty $(n=3)$ with informed consent and according to the Helsinki Declaration. The study was approved by the Ethics Committee of the Saarland Physicians Council (No. 270-17). Firstly, bone marrow-derived hMSCs were isolated and expanded as previously described [13-19]. Briefly, freshly isolated hMSCs were washed, centrifuged in Dulbecco's modified Eagle's medium (DMEM) and the pellet obtained was resuspended in a mixture of red blood cell lysing buffer and DMEM in equal ratios. The mixture was washed, pelleted, and resuspended in DMEM containing $10 \%$ fetal bovine serum with $100 \mathrm{U} / \mathrm{mL}$ penicillin and $100 \mu \mathrm{L} / \mathrm{mL}$ streptomycin. Cells were plated in T75 flasks and kept incubated overnight at $37^{\circ} \mathrm{C}$ under $5 \% \mathrm{CO}_{2}$, and the medium was removed and replaced by growth medium with recombinant FGF- $2(1 \mathrm{ng} / \mathrm{mL})$, with a medium change every 2-3 days. Cells were tested at passages 1-2 in order to avoid a shift in cell phenotype.

Human osteoarthritic (OA) cartilage biopsies excluding unaffected and fibrocartilage $(n=9 ; 6-\mathrm{mm}$ diameter; Mankin score = 7-9) randomly collected from the femoral condyle of patients undergoing total knee arthroplasty were used to create standardized osteochondral defects (OCDs) with a 1-mm biopsy punch $[20,21]$ and briefly kept in growth medium for 2-3 days (to avoid a shift in cell phenotype in the tissue) prior to direct implantation of the aggregates.

\subsection{Plasmids and $r A A V$ Vectors}

All vectors were produced from the AAV-2-based vector plasmid pSSV9 [22,23]. It is known that rAAV-lacZ carries the lacZ gene encoding the E. coli $\beta$-galactosidase ( $\beta$-gal). Further, rAAV-hTGF- $\beta$ carries a human transforming growth factor beta 1 (hTGF- $\beta$ ) cDNA and rAAV-hIGF-I, a human insulin-like growth factor I (hIGF-I) cDNA, both clones instead of lacZ in rAAV-lacZ, and all genes were controlled by the cytomegalovirus immediate-early (CMV-IE) promoter/enhancer [13-17,21,24]. Subsequently, rAAV vectors were prepared as conventional (not self-complementary) vectors using a helper-based system maintaining Adenovirus 5 and Ad8 in the 293 cell line (an adenovirus transformed 
human embryonic kidney packaging cell line) [13-17,21,24]. The vector preparations were purified by dialysis using the AAVanced Concentration Reagent and titrated by real-time PCR as previously described (approximately $10^{10}$ transgene copies $/ \mathrm{mL}$ and ratio recombinant functional viral particles to recombinant viral particles of about 1/500) [13-17,21,24].

\section{5. rAAV-Mediated Gene Transfer}

Bone marrow-derived hMSCs were prepared as high-density cultures $\left(2 \times 10^{5}\right.$ cells/aggregate $)$ and incubated in $150 \mu \mathrm{L}$ chondrogenic medium (DMEM high glucose $4.5 \mathrm{~g} / \mathrm{L}$, ITS ${ }^{+}$Premix, $1 \mathrm{mM}$ pyruvate, ascorbate 2-phosphate $37.5 \mathrm{ng} / \mathrm{mL}, 10^{-7} \mathrm{M}$ dexamethasone, TGF- $\beta 310 \mathrm{ng} / \mathrm{mL}$ ) overnight at $37^{\circ} \mathrm{C}$ under $5 \% \mathrm{CO}_{2}$ prior to vector addition $[13-17,21]$. Aggregates were then directly transduced with the vector treatments (TGF- $\beta /$ IGF-I, TGF- $\beta /$ lacZ, or IGF-I/lacZ: $40 \mu \mathrm{L}$ each vector/aggregate; lacZ: $80 \mu \mathrm{L}$ vector/aggregate; total $\mathrm{MOI}=8$ ) and $150 \mu \mathrm{L}$ chondrogenic medium was added for incubation at $37^{\circ} \mathrm{C}$ under $5 \% \mathrm{CO}_{2}$ for $24 \mathrm{~h}$. The (co-)transduced aggregates were then directly applied to the OCDs, with incubation in $750 \mu \mathrm{L}$ chondrogenic medium for 21 days. The chondrogenic medium was exchanged every $2-3$ days.

\subsection{Transgene Expression}

The expression of the candidate TGF- $\beta$ and IGF-I gene products was assessed by specific ELISAs. Briefly, the OCDs were washed twice with serum-free medium and kept in $750 \mu \mathrm{L}$ DMEM for $24 \mathrm{~h}$. Culture supernatants were then collected and centrifuged and tested following the manufacturer's recommendations on a GENios spectrophotometer/fluorometer (Tecan, Crailsheim, Germany) [15-17,24].

\subsection{Histological and Immonohistochemical Analyses}

The OCDs were harvested after 21 days, fixed in formaldehyde (4\%), washed with PBS, decalcified in $10 \%$ sodium citrate, $25 \%$ formic acid for two weeks at room temperature, and dehydrated in graded alcohol [21]. Histological and immunohistochemical analyses were performed on paraffin-embedded sections of OCDs $(10 \mu \mathrm{m})$. Sections were stained with hematoxylin and eosin (H\&E) (cellularization) and safranin $\mathrm{O}$ (matrix proteoglycans) [21]. The expression of type-II, -I, and -X collagen was monitored by immunohistochemical detection using specific primary antibodies, biotinylated secondary antibodies, and the $\mathrm{ABC}$ method with diaminobenzidine (DAB) as a chromogen [21]. Samples were analyzed under light microscopy (Olympus BX 45, Hamburg, Germany).

\subsection{Histomorphometric Analyses}

The transduction efficiencies (\% of TGF- $\beta^{+}$or IGF-I ${ }^{+}$immunoreactive cells to the total cell number), the cell densities (cells $/ \mathrm{mm}^{2}$ ), and the intensities of safranin $\mathrm{O}$ staining and those of type-II, -I, and -X collagen immunostaining (ratio tissue surface showing positive immunoreactivity for particular collagen/total tissue surface) were measured using the SIS analysisSIS program (Olympus), Adobe photoshop (Adobe Systems, Unterschleissheim, Germany), Scion Image (Scion Corporation, Frederick, MD, USA) at three random sites standardized for their surface or using serial histological or immunohistochemical sections [21]. Sections were also scored to evaluate the cartilage surrounding the OCDs (magnification $\times 10$ ) and the implanted aggregates (magnification $\times 20$ ) for uniformity and intensity using a modified Bern Score grading system [19,21]: 0 (no staining), 1 (heterogenous and/or weak staining), 2 (homogeneous and/or moderate staining), 3 (homogeneous and/or intense staining), 4 (very intense staining).

\subsection{Biochemical Analyses}

The OCDs were collected after 21 days of culture and digested in papain to determine the DNA contents by using the Hoechst 33,258 fluorometric assay, the proteoglycan contents by binding to the dimethylmethylene blue dye (DMMB), and the total cellular protein contents for normalization 
with the Pierce protein assay (Pierce Thermo Scientific, Fisher Scientific, Schwerte, Germany) [21]. Measurements were performed with a GENios spectrophotometer/fluorometer (Tecan).

\subsection{Real-Time RT-PCR Analyses}

Total RNA was extracted from the OCDs containing the aggregates but excluding bone tissue (RNeasy Protect Mini kit, Qiagen, Hilden, Germany) for reverse transcription (1st Strand cDNA Synthesis kit, avian myeloblastis virus (AMV) (Roche Applied Science, Mannheim, Germany). cDNA amplification was performed via SYBR Green real-time RT-PCR (Stratagene, Agilent Technologies, Waldbronn, Germany) maintaining initial incubation $\left(95^{\circ} \mathrm{C}, 10 \mathrm{~min}\right), 55$ cycles of amplification (denaturation $\left(95^{\circ} \mathrm{C}, 30 \mathrm{~s}\right)$, annealing $\left(55^{\circ} \mathrm{C}, 1 \mathrm{~min}\right)$, extension $\left(72{ }^{\circ} \mathrm{C}, 30 \mathrm{~s}\right)$, denaturation $\left(95^{\circ} \mathrm{C}\right.$ $1 \mathrm{~min}$ ), and final incubation $\left(55^{\circ} \mathrm{C}, 30 \mathrm{~s}\right)$. The primers employed were: SOX9 (chondrogenic marker) (forward 5'-ACACACAGCTCACTCGACCTTG-3'; reverse 5'-GGGAATTCTGGTTGGTCCTCT-3'), type-II collagen (COL2A1, chondrogenic marker) (forward 5'-GGACTTTTCTCCCCTCTCT-3; reverse 5'-GACCCGAAGGTCTTACAGGA-3'), aggrecan (ACAN, chondrogenic marker) (forward 5'-GAGATGGAGGGTGAGGTC-3'; reverse 5'-ACGCTGCCTCGGGCTTC-3'), type-I collagen (COL1A1, fibrocartilage and osteogenic marker) (forward 5'-ACGTCCTGGTGAAGTTGGTC-3'; reverse $5^{\prime}$-ACCAGGGAAGCCTCTCTCTC-3'), type-X collagen (COL10A1, hypertrophic marker) (forward 5'-CCCTCTTGTTAGTGCCAACC-3'; reverse 5'-AGATTCCAGTCCTTGGGTCA-3'), matrix metalloproteinase 13 (MMP13, marker of terminal differentiation and catabolism) (forward 5'-AATTTTCACTTTTGGCAATGA-3' ; reverse 5' -CAAATAATTTATGAAAAAGGGATGC-3'), and glyceraldehyde-3-phosphate dehydrogenase (GAPDH) (housekeeping gene and internal control) (forward 5'-GAAGGTGAAGGTCGGAGTC-3'; reverse 5'-GAAGATGGTGATGGGATTTC-3') [13-17]. Control conditions included reactions using water and non-reverse-transcribed mRNA. The specificity of the products was confirmed by melting curve analysis and agarose gel electrophoresis. The threshold cycle $(\mathrm{Ct})$ value for each gene of interest was measured for each amplified sample using MxPro QPCR software (Stratagene), and values were normalized to GAPDH expression by using the $2^{-\Delta \Delta \mathrm{Ct}}$ method [13-17].

\subsection{Statistical Analysis}

Each condition was performed in duplicate in three independent experiments for each patient. All hMSCs aggregates were tested for all experiments using the human OCDs. Results are expressed as the mean \pm standard deviation (SD). A t-test was employed with $p<0.05$ considered statistically significant.

\section{Results}

3.1. Effective rAAV-Mediated Co-Overexpression of TGF- $\beta$ and IGF-I in Human Osteochondral Defects Upon Implantation of Genetically Modified hMSC Aggregates

The rAAV vectors were first applied to hMSC aggregates $(n=3)$ and (co-)transduced aggregates were then directly implanted in human OCDs $(n=3)$ according to the study design (Figure 1 ) to test the ability of rAAV to co-overexpress the therapeutic TGF- $\beta$ and IGF-I candidates (TGF- $\beta$ /IGF-I) over time (21 days) versus independent gene transfer (TGF- $\beta /$ lacZ or IGF-I/lacZ) and control (lacZ) condition (endogenous growth factor expression). Effective expression of TGF- $\beta$ and IGF-I via rAAV was noted in the specific conditions examined, especially in the TGF- $\beta /$ IGF-I OCDs (Table 1, Table 2 and Figure 2).

The levels of TGF- $\beta$ production were higher in the TGF- $\beta$ /IGF-I than in the lacZ, TGF- $\beta /$ lacZ, and IGF-I/lacZ OCDs (3.6-, 1.7-, and 3.5-fold difference, respectively, $p \leq 0.001$ ) and in the TGF- $\beta /$ lacZ versus $l a c Z$ and IGF-I/lacZ OCDs (2.1-fold difference, $p \leq 0.010)$ while there was no difference between the IGF-I/lacZ and lacZ OCDs ( $p=0.500)$ (Table 1). The levels of IGF-I production were higher in the TGF- $\beta /$ IGF-I than in the lacZ, TGF- $\beta /$ lacZ, and IGF-I/lacZ OCDs (1.4-, 1.3-, and 1.1-fold difference, $p=0.010, p=0.010$, and $p=0.430$, respectively) and in the IGF-I/lac Z versus lac $Z$ and TGF- $\beta /$ lacZ OCDs 
(1.3-fold difference, $p \leq 0.040$ ) while there was no difference between the TGF- $\beta /$ lacZ and lacZ OCDs $(p=0.353)$ (Table 1).

Table 1. Transgene expression in human OCD supernatants following implantation of rAAV-transduced hMSC aggregates (day 21). The levels of TGF- $\beta$ production are in $\mathrm{pg} / \mathrm{mL}$ and those of IGF-I in $\mathrm{pg} / \mathrm{mL}$. Data are given as mean \pm SD. Statistically significant relative to ${ }^{\mathrm{a}}$ lacZ, ${ }^{\mathrm{b}} \mathrm{TGF}-\beta /$ lacZ, and ${ }^{\mathrm{c}} \mathrm{IGF}-\mathrm{I} /$ lacZ; TGF- $\beta^{+}$, TGF- $\beta$-positive; IGF-I ${ }^{+}$, and IGF-positive.

\begin{tabular}{ccccc}
\hline Assay & lacZ & TGF- $\beta /$ lac Z & IGF-I/lacZ & TGF- $\beta /$ IGF-I \\
\hline${\text { TGF- } \beta^{+}}^{+}$ & $156 \pm 74$ & $333 \pm 58^{\mathrm{a}, \mathrm{c}}$ & $158 \pm 90$ & $556 \pm 70^{\mathrm{a}, \mathrm{b}, \mathrm{c}}$ \\
IGF-I $^{+}$ & $53 \pm 7$ & $55 \pm 8$ & $71 \pm 16^{\mathrm{a}, \mathrm{b}}$ & $73 \pm 18^{\mathrm{a}, \mathrm{b}}$ \\
\hline
\end{tabular}

Table 2. Histomorphometric analyses in human osteochondral defects OCDs following implantation of rAAV-transduced hMSC aggregates (day 21). TGF- $\beta$-positive (TGF- $\beta^{+}$) and IGF-positive (IGF-I ${ }^{+}$) cells are in \%. The cell densities are as cells $/ \mathrm{mm}^{2}$. Stained (safranin O) and immunostained (type-II, -I, and -X collagen) sections were scored for uniformity and intensity according to modified Bern Score grading system [19] as: 0 (no staining), 1 (heterogenous and/or weak staining), 2 (homogeneous and/or moderate staining), 3 (homogeneous and/or intense staining) and 4 (very intense staining). Data are given as mean $\pm \mathrm{SD}$. Statistically significant relative to ${ }^{\mathrm{a}}$ lac $\mathrm{Z},{ }^{\mathrm{b}} \mathrm{TGF}-\beta /$ lacZ, and ${ }^{\mathrm{c}} \mathrm{IGF}-\mathrm{I} / \mathrm{lacZ}$.

\begin{tabular}{|c|c|c|c|c|c|}
\hline \multicolumn{2}{|c|}{ Assay } & \multirow{3}{*}{$\begin{array}{c}\text { lacZ } \\
12 \pm 2 \\
2 \pm 1\end{array}$} & \multirow{3}{*}{$\begin{array}{c}\text { TGF- } \beta / \text { lac Z } \\
77 \pm 8^{\mathrm{a}, \mathrm{c}} \\
62 \pm 6^{\mathrm{a}, \mathrm{c}}\end{array}$} & \multirow{3}{*}{$\begin{array}{c}\text { IGF-I/lacZ } \\
12 \pm 5 \\
3 \pm 1\end{array}$} & \multirow{3}{*}{$\begin{array}{c}\text { TGF- } \beta / \text { IGF-I } \\
93 \pm 1^{a, b, c} \\
74 \pm 6^{a, b, c}\end{array}$} \\
\hline & OCD & & & & \\
\hline TGF- $\beta^{+}$cells & surrounding cartilage & & & & \\
\hline \multirow{2}{*}{$\mathrm{IGF}^{+} \mathrm{I}^{+}$cells } & OCD & $13 \pm 3$ & $18 \pm 4$ & $76 \pm 3^{a, b}$ & $86 \pm 2^{a, b, c}$ \\
\hline & surrounding cartilage & $6 \pm 2$ & $15 \pm 4$ & $56 \pm 3^{a, b}$ & $64 \pm 5^{a, b, c}$ \\
\hline \multirow{2}{*}{ Cell densities } & OCD & $3467 \pm 115$ & $5767 \pm 1156^{a}$ & $5608 \pm 300^{a}$ & $11,308 \pm 1556^{a, b, c}$ \\
\hline & surrounding cartilage & $145 \pm 21$ & $238 \pm 75^{a, c}$ & $168 \pm 11$ & $286 \pm 80^{a, b, c}$ \\
\hline \multirow{2}{*}{ Safranin $\mathrm{O}$} & OCD & $0.3 \pm 0.4$ & $2.1 \pm 0.8^{\mathrm{a}, \mathrm{c}}$ & $0.1 \pm 0.4$ & $2.4 \pm 0.7^{\mathrm{a}, \mathrm{c}}$ \\
\hline & surrounding cartilage & $1.3 \pm 0.5$ & $2.6 \pm 1.0^{\mathrm{a}}$ & $1.9 \pm 0.6^{\mathrm{a}}$ & $3.8 \pm 0.5^{\mathrm{a}, \mathrm{b}, \mathrm{c}}$ \\
\hline \multirow{2}{*}{ Type-II collagen } & OCD & $1.0 \pm 0.8$ & $3.0 \pm 0.1^{a, c}$ & $2.3 \pm 0.5^{a}$ & $3.8 \pm 0.5^{\mathrm{a}, \mathrm{b}, \mathrm{c}}$ \\
\hline & surrounding cartilage & $0.5 \pm 0.1$ & $2.5 \pm 0.6^{\mathrm{a}, \mathrm{c}}$ & $1.8 \pm 0.5^{\mathrm{a}}$ & $3.0 \pm 0.8^{a, c}$ \\
\hline \multirow{2}{*}{ Type-I collagen } & OCD & $3.1 \pm 0.8$ & $1.5 \pm 0.7^{\mathrm{a}, \mathrm{c}}$ & $3.0 \pm 0.5$ & $1.1 \pm 0.4^{\mathrm{a}, \mathrm{c}}$ \\
\hline & surrounding cartilage & $2.9 \pm 0.6$ & $2.0 \pm 0.8^{a}$ & $2.6 \pm 0.7$ & $1.5 \pm 0.5^{\mathrm{a}, \mathrm{c}}$ \\
\hline \multirow{2}{*}{ Type- $X$ collagen } & OCD & $3.0 \pm 0.8$ & $1.9 \pm 1.1^{\mathrm{a}}$ & $2.3 \pm 0.9$ & $1.3 \pm 0.5^{\mathrm{a}}$ \\
\hline & surrounding cartilage & $2.9 \pm 0.6$ & $2.6 \pm 0.5$ & $2.1 \pm 1.0$ & $0.8 \pm 0.7^{a, b, c}$ \\
\hline
\end{tabular}

Immunoreactivity to TGF- $\beta$ was higher in the TGF- $\beta /$ IGF-I than in the lac $Z$, TGF- $\beta /$ lacZ, and IGF-I/lacZ OCDs (7.8-, 1.2-, and 7.8-fold difference, respectively, $p \leq 0.020)$ and in the TGF- $\beta /$ lacZ versus $l a c Z$ and IGF-I/lac Z OCDs (6.4-fold difference, $p \leq 0.001$ ) while there was no difference between the IGF-I/lac $Z$ and lacZ OCDs $(p=0.500)$ (Figure 2 and Table 2). In the surrounding cartilage, TGF- $\beta$ immunoreactivity was higher in the TGF- $\beta /$ IGF-I than in the lac $Z$, TGF- $\beta /$ lac $Z$, and IGF-I/lac $Z$ samples (37-, 1.2-, and 24.7-fold difference, respectively, $p \leq 0.040$ ) and in the TGF- $\beta /$ lacZ versus lacZ and IGF-I/lacZ samples (31- and 20.7-fold difference, respectively, $p=0.005$ ) while there was no difference between the IGF-I/lac $Z$ and lac $Z$ samples (1.5-fold difference, $p=0.220$ ) (Figure 2 and Table 2). Immunoreactivity to IGF-I was higher in the TGF- $\beta /$ IGF-I than in the lacZ, TGF- $\beta /$ lacZ, and IGF-I/lacZ OCDs (6.6-, 4.8-, and 1.2-fold difference, respectively, $p \leq 0.002)$ and in the IGF-I/lacZ versus $l a c Z$ and TGF- $\beta /$ lac $Z$ OCDs (5.8 and 4.2-fold difference, respectively, $p \leq 0.001$ ) while there was no difference between the TGF- $\beta /$ lac $Z$ versus lacZ OCDs $(p=0.077)$ (Figure 2 and Table 2). In the surrounding cartilage, IGF-I immunoreactivity was higher in the TGF- $\beta /$ IGF-I than in the lacZ, TGF- $\beta /$ lacZ, and IGF-I/lacZ samples (10.7-, 4.3-, and 1.2-fold difference, respectively, $p \leq 0.041$ ) and in the IGF-I/lac Z versus lacZ and TGF- $\beta /$ lacZ samples (9.3- and 3.7-fold difference, respectively, $p \leq 0.020$ ) while there was no difference between the TGF- $\beta /$ lac $Z$ versus lac $Z$ samples $(p=0.240)$ (Figure 2 and Table 2). 

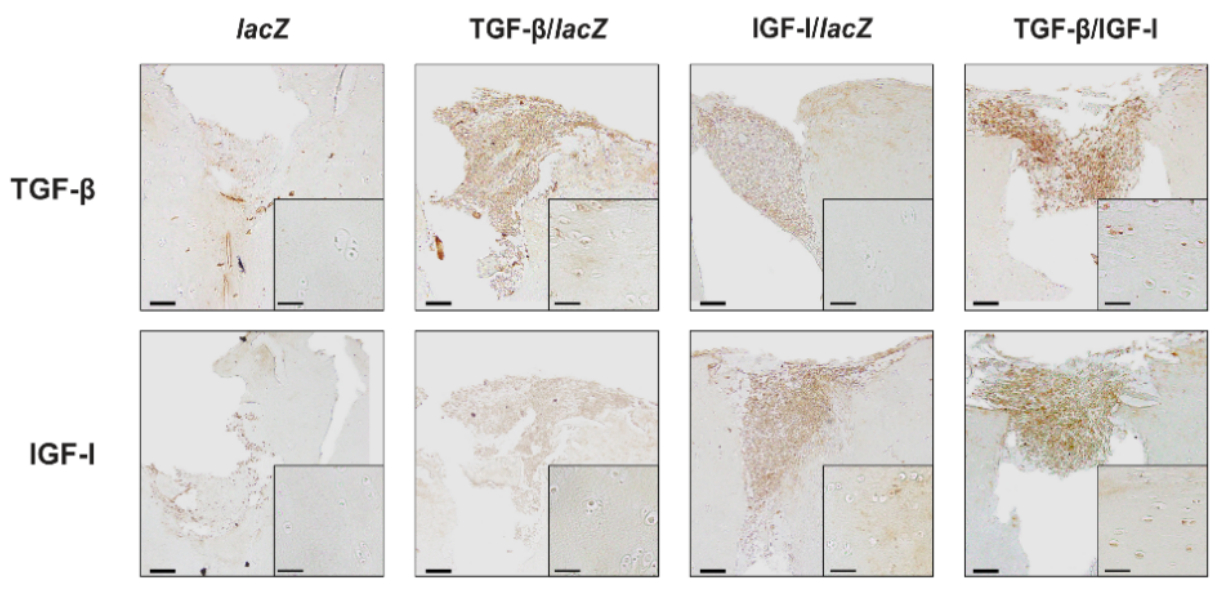

Figure 2. Detection of transgene (TGF- $\beta$, IGF-I) overexpression in human OCDs following implantation of rAAV-transduced hMSC aggregates. Aggregates were cotransduced with rAAV TGF- $\beta /$ IGF-I, TGF- $\beta /$ lacZ, IGF-I/lacZ or transduced with rAAV lacZ and implanted in human OCDs as described in Figure 1 and in the Materials and Methods. Samples were processed after 21 days to detect the expression of TGF- $\beta$ and of IGF-I by immunohistochemistry (magnification $\times 10$; insets showing the surrounding cartilage in the region immediately adjacent to the implanted pellets at magnification $\times 20$; representative data). Scale bars: $100 \mu \mathrm{m}$, insets: $50 \mu \mathrm{m}$.

3.2. Biological and Chondrogenic Differentiation Activities in Human Osteochondral Defects Mediated by Co-Overexpression of TGF- $\beta$ and IGF-I via rAAV in Implanted hMSC Aggregates

The hMSC aggregates $(n=3)$ transduced with the various rAAV vectors were next directly implanted in human OCDs $(n=3)$ to determine the capacity of the TGF- $\beta$ /IGF-I combination to enhance the proliferative, anabolic, and chondrogenic activities in sites of transplantation in situ over time (21 days) versus independent gene (TGF- $\beta /$ lacZ or IGF-I/lacZ) and control (lacZ) gene treatments.

The DNA contents were higher in the TGF- $\beta /$ IGF-I versus lacZ, TGF- $\beta /$ lac Z, and IGF-I/lacZ OCDs $(1.3-, 1.2-$, and 1.3-fold difference, respectively, $p \leq 0.020)$ and in the TGF- $\beta /$ lac $Z$ versus $l a c Z$ and IGF-I/lacZ OCDs (1.2-fold difference, $p \geq 0.060$ ) while there was no difference between the IGF-I/lacZ and lacZ OCDs $(p=0.440)$ (Table 3$)$.

Table 3. Biological activities in human OCDs following implantation of rAAV-transduced hMSC aggregates (day 21). The DNA contents are in $\mathrm{ng} / \mu \mathrm{g}$ total proteins, the proteoglycan contents in $\mu \mathrm{g} / \mathrm{mg}$ total proteins, and the proteoglycan/DNA contents in $\mu \mathrm{g} / \mathrm{ng}$. Data are given as mean \pm SD. Statistically significant relative to ${ }^{\mathrm{a}} \mathrm{lac} Z,{ }^{\mathrm{b}} \mathrm{TGF}-\beta /$ lac $Z$, and ${ }^{\mathrm{c}} \mathrm{IGF-I} / \mathrm{lac} Z$.

\begin{tabular}{ccccc}
\hline Assay & lac $Z$ & TGF- $\beta$ /lacZ & IGF-I/lacZ & TGF- $\beta /$ IGF-I \\
\hline DNA & $0.39 \pm 0.26$ & $0.45 \pm 0.30$ & $0.39 \pm 0.25$ & $0.52 \pm 0.32^{\mathrm{a}, \mathrm{b}, \mathrm{c}}$ \\
Proteoglycans & $12 \pm 7$ & $17 \pm 12^{\mathrm{a}}$ & $15 \pm 8$ & $22 \pm 13^{\mathrm{a}, \mathrm{b}, \mathrm{c}}$ \\
Proteoglycans/DNA & $0.11 \pm 0.05$ & $0.13 \pm 0.07^{\mathrm{a}}$ & $0.12 \pm 0.05$ & $0.15 \pm 0.07^{\mathrm{a}, \mathrm{b}, \mathrm{c}}$ \\
\hline
\end{tabular}

The cell densities were higher in the TGF- $\beta /$ IGF-I versus lacZ, TGF- $\beta /$ lacZ, and IGF-I/lacZ OCDs (3.2-, 2-, and 2-fold difference, respectively, $p \leq 0.020)$, in the TGF- $\beta /$ lac $Z$ versus lacZ OCDs (1.7-fold difference, $p=0.044$ ), and in the IGF-I/lacZ versus lacZ OCDs (1.6-fold difference, $p=0.006$ ) while there was no difference between the TGF- $\beta /$ lacZ and IGF-I/lacZ OCDs $(p=0.390)$ (Figure 3 and Table 2). In the cartilage surrounding the OCDs, the cell densities were higher in the TGF- $\beta /$ IGF-I versus lac $Z$, TGF- $\beta /$ lac $Z$, and IGF-I/lacZ samples (2-, 1.2-, and 1.7-fold difference, respectively, $p \leq 0.040$ ), in the TGF- $\beta /$ lac $Z$ versus lac $Z$ and IGF-I/lacZ samples (1.6- and 1.4-fold difference, respectively, $p \leq 0.040$ ), and in the IGF-I/lacZ and lacZ samples (1.2-fold difference, $p=0.090$ ) (Figure 3 and Table 2). 


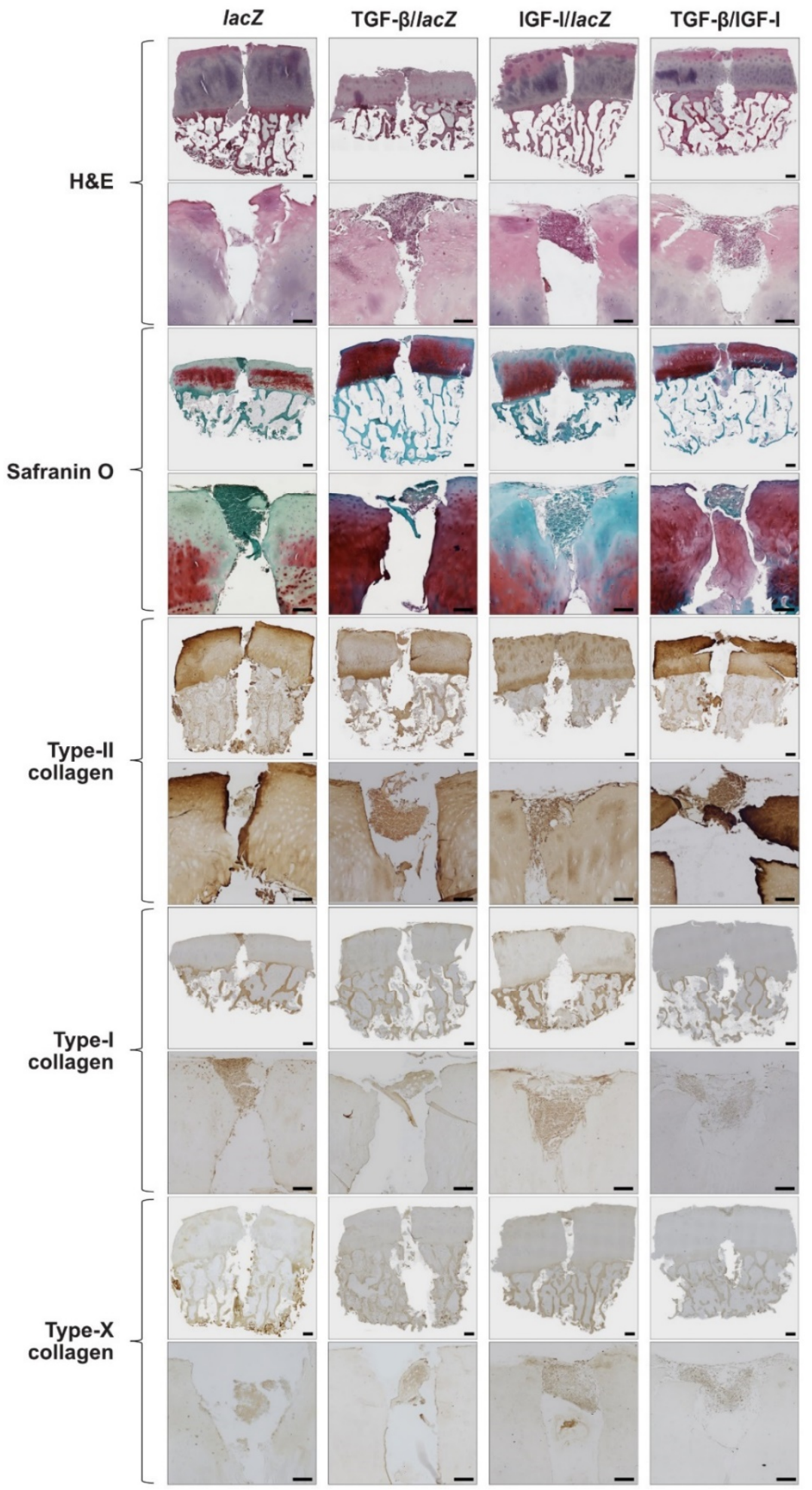

Figure 3. Biological, chondrogenic, osteogenic, and hypertrophic differentiation activities in human OCDs following implantation of rAAV-transduced hMSC aggregates. Aggregates were cotransduced with rAAV TGF- $\beta /$ IGF-I, TGF- $\beta /$ lacZ, IGF-I/lacZ or transduced with $\mathrm{rAAV}$ lacZ and implanted in human OCDs as described in Figures 1 and 2 and in the Materials and Methods. Samples were processed after 21 days to evaluate cellularity (H\&E staining) and the deposition of matrix proteoglycans (safranin O staining), type-II/-I/-X collagen (immunohistochemistry) (for each type of staining: top panel at magnification $\times 10$ with scale bars of $500 \mu \mathrm{m}$, bottom panels including the region immediately adjacent to the implanted pellets at magnification $\times 20$ with scale bars of $200 \mu \mathrm{m}$; representative data). 
The anabolic and chondrogenic differentiation activities were higher in the TGF- $\beta /$ IGF-I versus lacZ, TGF- $\beta /$ lacZ, and IGF-I/lacZ OCDs (proteoglycans: 1.8-, 1.3-, and 1.5-fold difference, respectively, $p \leq 0.020$; proteoglycans/DNA: 1.4-, 1.2-, and 1.3-fold difference, respectively, $p \leq 0.030$; safranin O: 8-, 1.1-, and 24-fold difference, $p \leq 0.001, p=0.260$, and $p \leq 0.001$, respectively; type-II collagen: 3.8-, and 1.7-fold difference, respectively, $p \leq 0.030$ ), in the TGF- $\beta /$ lac Z versus lac $Z$ and IGF-I/lacZ OCDs (proteoglycans: 1.4 - and 1.2-fold difference, $p=0.030$ and $p=0.200$, respectively; proteoglycans/DNA: 1.2- and 1.1-fold difference, respectively, $p=0.030$ and $p=0.150$; safranin O: 7- and 21-fold difference, respectively, $p \leq 0.001$; type-II collagen: 3 - and 1.3-fold difference, respectively, $p \leq 0.030$ ), and in the IGF-I/lacZ versus lacZ OCDs (proteoglycans: 1.3 -fold difference, $p=0.090$; proteoglycans/DNA: 1.1-fold difference, $p=0.280$; type-II collagen: 2.3 -fold difference, $p=0.010$ ) while there was no difference between the IGF-I/lacZ and lacZ OCDs for safranin O staining ( $p=0.500)$ (Table 2, Table 3 and Figure 3). In the cartilage surrounding the OCDs, the chondrogenic differentiation activities were higher in the TGF- $\beta /$ IGF-I versus lacZ, TGF- $\beta /$ lacZ, and IGF-I/lacZ samples (safranin O: 2.9-, 1.5-, and 2-fold difference, respectively, $p \leq 0.030$; type-II collagen: $6-, 1.2-$, and 1.7-fold difference, $p=0.002, p=0.100$, and $p=0.040$, respectively), in the TGF- $\beta /$ lacZ versus lacZ and IGF-I/lacZ samples (safranin O: 2 - and 1.4-fold difference, $p=0.010$ and $p=0.080$, respectively; type-II collagen: 5- and 1.4-fold difference, respectively, $p \leq 0.030$ ), and in the IGF-I/lac Z versus lac Z samples (safranin O: 1.5-fold difference, $p \leq 0.030$; type-II collagen: 3.6-fold difference, $p=0.040$ ) (Table 2, Table 3 and Figure 3).

3.3. Influence of Co-Overexpression of TGF- $\beta$ and IGF-I via rAAV Upon the Osteogenic and Hypertrophic Differentiation Activities in Human Osteochondral Defects Upon Implantation of Genetically Modified hMSC Aggregates

The hMSC aggregates $(n=3)$ transduced with rAAV were then directly implanted in human OCDs $(n=3)$ to determine the potential influence of the TGF- $\beta$ /IGF-I combination on the osteogenic and hypertrophic activities in transplanted sites in situ over time (21 days) versus independent gene delivery (TGF- $\beta /$ lacZ or IGF-I/lacZ) and control (lacZ) treatment.

The osteogenic differentiation activities (type-I collagen deposition) were lower in the TGF- $\beta /$ IGF-I versus lac $Z$, TGF- $\beta /$ lac $Z$, and IGF-I/lacZ OCDs (2.8-, 1.4-, and 2.7-fold difference, $p \leq 0.001, p=0.090$, and $p \leq 0.001$, respectively) and in the TGF- $\beta /$ lacZ versus lac $Z$ and IGF-I/lacZ OCDs (2.1- and 2-fold difference, respectively, $p \leq 0.001$ ) while there was no difference between the IGF-I/lac $Z$ and lacZ OCDs $(p=0.400)$ (Figure 3 and Table 2$)$. In the cartilage surrounding the OCDs, the osteogenic differentiation activities were lower in the TGF- $\beta /$ IGF-I versus lacZ, TGF- $\beta /$ lacZ, and IGF-I/lacZ samples (1.9-, 1.3-, and 1.7-fold difference, $p \leq 0.001, p=0.120$, and $p \leq 0.001$, respectively), in the TGF- $\beta /$ lac $Z$ versus lac $Z$ and IGF-I/lacZ samples (1.5- and 1.3-fold difference, $p=0.020$ and $p=0.130$, respectively), and in the IGF-I/lacZ and lacZ samples (1.1-fold difference, $p=0.230$ ) (Figure 3 and Table 2).

The hypertrophic differentiation activities (type- $X$ collagen deposition) were lower in the TGF- $\beta /$ IGF-I versus lacZ, TGF- $\beta /$ lacZ, and IGF-I/lacZ OCDs (2.3-, 1.5-, and 1.8-fold difference, $p \leq 0.001$, $p=0.100$, and $p=0.100$, respectively), in the TGF- $\beta /$ lac Z versus lac Z and IGF-I/lacZ OCDs (1.6- and 1.2-fold difference, respectively, $p \leq 0.001$ and $p=0.260$, respectively), and in the IGF-I/lacZ versus lac $Z$ OCDs (1.3-fold difference, $p=0.090$ ) (Figure 3 and Table 2). In the cartilage surrounding the OCDs, the hypertrophic differentiation activities were lower in the TGF- $\beta /$ IGF-I versus lacZ, TGF- $\beta /$ lacZ, and IGF-I/lacZ samples (3.6-, 3.3-, and 2.6-fold difference, respectively, $p \leq 0.007$ ), in the TGF- $\beta /$ lacZ versus lac $Z$ samples (1.1-fold difference, $p=0.230$ ), in the IGF-I/lac $Z$ versus samples (1.4-fold difference, $p=0.060$ ), and and in the IGF-I/lac Z versus TGF- $\beta /$ lac $Z$ samples (1.2-fold difference, $p=0.230$ ) (Figure 3 and Table 2). 
3.4. Real-Time RT-PCR Analyses in Human Osteochondral Defects Mediated by Co-Overexpression of TGF- $\beta$ with IGF-I via rAAV in Implanted hMSC Aggregates

These results were corroborated by real-time RT-PCR analysis in human OCDs $(n=3)$ where rAAV-transduced (TGF- $\beta /$ IGF-I versus TGF- $\beta /$ lacZ, IGF-I/lacZ, and lacZ) hMSC aggregates $(n=3)$ were implanted over time (21 days) (Figure 4).
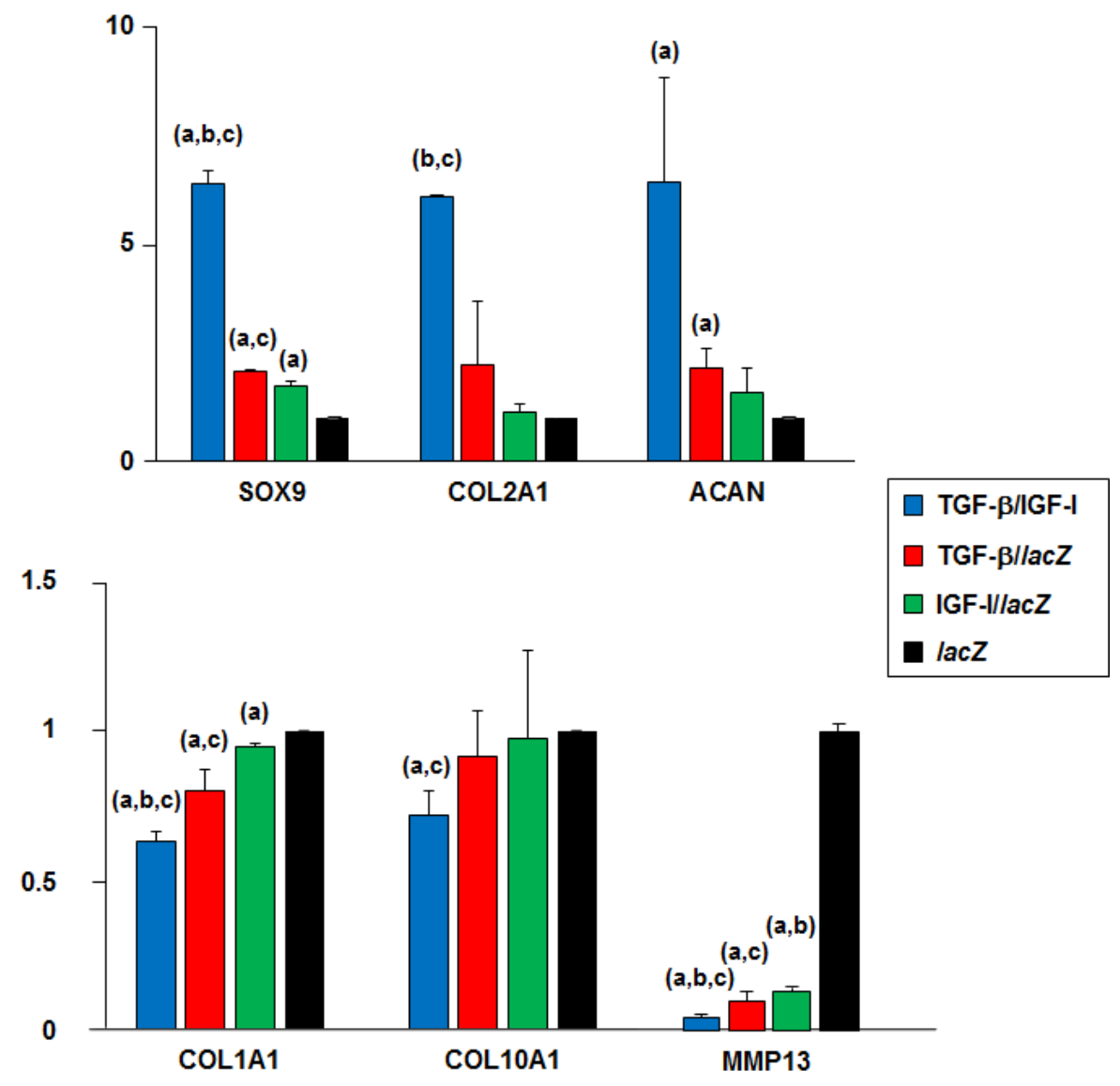

Figure 4. Real-time RT-PCR analyses in human OCDs following implantation of rAAV-transduced hMSC aggregates. Aggregates were cotransduced with rAAV TGF- $\beta /$ IGF-I, TGF- $\beta /$ lacZ, IGF-I/lacZ or transduced with rAAV lacZ and implanted in human OCDs as described in Figures 1-3 and in the Materials and Methods. Samples were processed after 21 days to monitor the gene expression profiles by real-time RT-PCR as described in the Materials and Methods. The genes analyzed included the transcription factor SOX9, type-II collagen (COL2A1), aggrecan (ACAN), type-I collagen (COL1A1), type- $X$ collagen (COL10A1), and matrix metalloproteinase 13 (MMP13), with GAPDH serving as a housekeeping gene and internal control. Threshold cycle $(\mathrm{Ct})$ values were obtained for each target and GAPDH as a control for normalization, and fold inductions (relative to OCDs where lacZ aggregates were implanted) were measured using the $2^{-\Delta \Delta C t}$ method. Statistically significant relative to a lac $Z$, ${ }^{\mathrm{b}} \mathrm{TGF}-\beta /$ lacZ, and ${ }^{\mathrm{c}} \mathrm{IGF}-\mathrm{I} / \mathrm{lac} Z$.

Enhanced chondrogenic differentiation was observed by higher SOX9 expression in the TGF- $\beta /$ IGF-I versus lacZ, TGF- $\beta /$ lacZ, and IGF-I/lacZ OCDs (6.4-, 3.1-, and 3.7-fold difference, $p \leq 0.014)$, in the TGF- $\beta /$ lac $Z$ versus lac $Z$ and IGF-I/lacZ OCDs (2.1- and 1.7-fold difference, respectively, $p \leq 0.042$ ), and in the IGF-I/lacZ versus lac Z OCDs (1.7-fold difference, $p \leq 0.001$ ) (Figure 4 ). Enhanced chondrogenic COL2A1 expression was also seen in the TGF- $\beta /$ IGF-I versus lacZ, TGF- $\beta /$ lac $Z$, and IGF-I/lacZ OCDs (6.1-, 2.7-, and 5.3-fold difference, $p=0.057, p=0.032$, and $p \leq 0.001$, respectively), in the TGF- $\beta /$ lac $Z$ versus lacZ and IGF-I/lacZ OCDs (2.2- and 2-fold difference, respectively, $p \geq 0.099$ ), and in the IGF-I/lacZ versus lacZ OCDs (1.1-fold difference, $p=0.118$ ) (Figure 4). Higher chondrogenic ACAN expression was 
also evidenced in the TGF- $\beta$ /IGF-I versus lacZ, TGF- $\beta /$ lacZ, and IGF-I/lacZ OCDs (6.4-, 3-, and 4.1-fold difference, $p=0.012, p=0.066$, and $p=0.054$, respectively), in the TGF- $\beta /$ lac $Z$ versus lac $Z$ and IGF-I/lacZ OCDs (2.2- and 1.4-fold difference, $p=0.007$ and $p=0.186$, respectively), and in the IGF-I/lac $Z$ versus lacZ OCDs (1.6-fold difference, $p=0.083$ ) (Figure 4).

Restricted osteogenic differentiation was seen by lower COL1A1 expression in the TGF- $\beta /$ IGF-I versus lacZ, TGF- $\beta /$ lacZ, and IGF-I/lacZ OCDs (1.6-, 1.3-, and 1.5-fold difference, respectively, $p \leq 0.001$ ), in the TGF- $\beta /$ lac $Z$ versus lac $Z$ and IGF-I/lacZ OCDs (1.2-fold difference, $p \leq 0.036$ ), and in the IGF-I/lac $Z$ versus lacZ OCDs (1.1-fold difference, $p=0.002$ ) (Figure 4 ).

Reduced hypertrophic differentiation was noted by lower COL10A1 expression in the TGF- $\beta /$ IGF-I versus lacZ, TGF- $\beta /$ lacZ, and IGF-I/lacZ OCDs (1.4-, 1.3-, and 1.4-fold difference, $p=0.002, p=0.069$, and $p=0.018$, respectively) and in the TGF- $\beta /$ lac $Z$ versus IGF-I/lacZ and lacZ OCDs (1.1-fold difference, $p \geq 0.181$ ) while no difference was reported between the IGF-I/lacZ and lacZ OCDs ( $p=0.440$ ) (Figure 4).

Decreased catabolic processes were also observed by lower MMP13 expression in the TGF- $\beta /$ IGF-I versus lacZ, TGF- $\beta /$ lacZ, and IGF-I/lacZ OCDs (16.7-, 1.4-, and 1.7-fold difference, $p \leq 0.005)$, in the TGF- $\beta /$ lac $Z$ versus IGF-I/lac $Z$ and lacZ OCDs (1.3- and 12.5-fold difference, $p \leq 0.001$ ), and in the IGF-I/lacZ and lacZ OCDs (10-fold difference, $p \leq 0.001$ ) (Figure 4).

\section{Discussion}

Cell-based strategies using the application of progenitor cells to focal cartilage defects may be of strong therapeutic value to enhance the intrinsic healing processes in sites of cartilage damage [7], especially following modification of such cellular platforms by gene therapy procedures that aim at stably triggering their chondroreparative activities $[8,9]$. Here, we tested the ability of the clinically adapted rAAV gene transfer vectors to co-deliver the highly chondrogenic TGF- $\beta$ and IGF-I growth factors $[11,15,16]$ to hMSCs for implantation in a model of human OCD that provides a natural environment similar to that noted in patients in vivo $[20,21]$ as a means to repopulate the defects upon stimulation of the local healing processes relative to independent gene treatments and control (reporter gene vector) condition.

The data first indicate that rAAV is capable of successfully promoting the concomitant, sustained overexpression of TGF- $\beta$ with IGF-I in hMSCs transplanted in human OCDs over the entire period of evaluation (at least 21 days) relative to single and reporter gene treatments, in agreement with the ability of rAAV to transduce and be maintained in such targets [11,13-16], especially in a simultaneous fashion [17]. Of note, the amounts of each respective growth factor produced in the OCDs were significantly higher upon the application of hMSCs co-transduced with TGF- $\beta /$ IGF-I relative to single, independent candidate gene treatments at similar vector doses, suggesting a possible reciprocal regulation of growth factor expression as previously noted in articular chondrocytes [25]. The production levels of TGF- $\beta$ and IGF-I raised from implanted TGF- $\beta /$ lacZ- or IGF-I/lacZ-treated hMSCs were comparable to those measured in our previous work using solely rAAV-hTGF- $\beta$ or rAAV-hIGF-I in hMSCs in vitro at equivalent MOIs $(\sim 70-300 \mathrm{pg} / \mathrm{mL}$ at MOI $=8)[15,16]$ or the current combination in settings in vitro aiming at directly rejuvenating the cells $(\sim 50-100 \mathrm{pg} / \mathrm{mL}$ at MOI = 8) [18]. Interestingly, transgene (co)-expression was also noted in the cartilage surrounding the defects where the respective candidate treatments were applied, showing the potentially beneficial production of the growth factors via rAAV-modified, transplanted cells at a distance. It remains to be seen whether too high and/or prolonged levels of growth factor co-overexpression may have a detrimental impact on tissue repair in this model system or in vivo-however, such an issue might be addressed by applying various (lower) vector doses or using regulatable (tetracycline-controlled) or tissue-specific promoters (sox9, type-II collagen) [26] instead of the strong CMV-IE regulatory element. While no immune responses were expected in such a model ex vivo as it lacks the full spectrum of immune components, they may occur in vivo [27] although to a low extent as rAAV has been reported for its absence of deleterious effects when directly applied to focal defects in vivo [28]. 
The results next show that significant, prolonged TGF- $\beta$ /IGF-I co-overexpression from co-transduced, implanted hMSCs triggered the biological and chondrodifferentiation activities in human OCDs over time (cell proliferation, proteoglycan/type-II collagen deposition) more effectively than when using each individual candidate gene treatment and versus control (lacZ) condition, as a possible growth factor intercooperation [25] and concordant with the properties of TGF- $\beta$ and IGF-I $[5,6,11,29]$ and with our work using the vectors independently $[15,16]$ or simultaneously in a direct transfer approach [18]. Such effects were also observed in the cartilage surrounding the defects, likely due to the expression of the candidate transgenes at a distance and/or to the paracrine effects of the factors secreted. A degree of variability was noted between samples, reflecting the different features and background of the individual donors, but in good agreement with previous observations by Mackay et al. [6] who reported similar discrepancies between human donors. Of note, as the gene expression profiles were tested in bone-free OCD-implant systems due to the limited size of the cell-confined aggregates, the contribution of the implants to such profiles remains to be determined [20] versus a possible impact of the (slightly less active) chondrocytes in the surrounding cartilage. Despite such results, integration between the implant and the host cartilage and self-repair (even for a small, 1-mm lesion) did not fully occur, in agreement with our previous observations using such a model system [20], an outcome that might be achieved at much longer time points [30,31].

Finally, the data demonstrate the ability of combined rAAV-mediated TGF- $\beta /$ IGF-I co-overexpression in implanted hMSCs to prevent undesirable hypertrophic, terminal differentiation, and osteogenic differentiation as well as catabolic processes over time in treated OCDs relative to single candidate gene treatments and the control lac $Z$ condition, probably due to higher levels of SOX9 expression, a transcription factor known for its anti-hypertrophic and anti-catabolic activities [14,32], and in agreement with our findings using a direct approach [18]. This is in contrast with our previous findings when applying either rAAV-hTGF- $\beta$ or rAAV-hIGF-I to hMSCs in vitro $[15,16]$ yet in these studies, a higher MOI was provided to the cells (MOI $=20$ while we used an MOI $=8$ here, i.e., a 2.5 -fold difference), showing that the optimal treatment will be a function of the vector doses applied. Here also, these effects were seen in the cartilage surrounding the defects, again probably resulting from the expression of the transgenes at a distance and/or to paracrine effects of the products.

\section{Conclusions}

The present findings show the benefits of cell- and gene-based therapy using multiple therapeutic rAAV gene transfer procedures in order to regenerate human articular cartilage lesions with an adapted phenotype in a natural environment. Work is ongoing to evaluate the potential benefits of this indirect regenerative approach in clinically relevant animal models of (orthotopic) cartilage defects in vivo and to evaluate possible immune responses [33,34]. Overall, the current data provide a basis for the future treatment of focal cartilage defects in human individuals using the patient's self-reparative progenitor cells.

Author Contributions: Conceptualization, M.C.; methodology, S.M., J.K.V., A.R.-R., and G.S.; software, S.M. and M.C.; validation, S.M., J.K.V., A.R.-R., G.S., and M.C.; formal analysis, S.M. and M.C.; investigation, S.M., J.K.V., A.R.-R., and G.S.; data curation, S.M. and M.C.; writing-original draft preparation, S.M. and M.C.; writing-review and editing, S.M., J.K.V., A.R.-R., G.S., and M.C.; visualization, S.M. and M.C.; supervision, M.C.; funding acquisition, M.C.

Funding: This research was funded by the Deutsche Arthrose-Hilfe e.V. (MC).

Acknowledgments: We thank R.J. Samulski (The Gene Therapy Center, University of North Carolina, Chapel Hill, NC, USA), X. Xiao (The Gene Therapy Center, University of Pittsburgh, Pittsburgh, PA, USA), and E.F. Terwilliger (Division of Experimental Medicine, Harvard Institutes of Medicine and Beth Israel Deaconess Medical Center, Boston, MA, USA) for providing the genomic AAV-2 plasmid clones and the 293 cell line.

Conflicts of Interest: The authors declare that they have no competing interests. The funders had no role in the design of the study; in the collection, analyses, or interpretation of data; in the writing of the manuscript, or in the decision to publish the results. 


\section{References}

1. Buckwalter, J.A. Articular cartilage: Injuries and potential for healing. J. Orthop. Sports Phys. Ther. 1998, 28, 192-202. [CrossRef] [PubMed]

2. O'Driscoll, S.W. The healing and regeneration of articular cartilage. J. Bone Joint Surg. Am. 1998, 80, $1795-1812$. [CrossRef] [PubMed]

3. Hunziker, E.B. Articular cartilage repair: Basic science and clinical progress. A review of the current status and prospects. Osteoarthr. Cartil. 2002, 10, 432-463. [CrossRef] [PubMed]

4. Madry, H.; Grün, U.W.; Knutsen, G. Cartilage repair and joint preservation: Medical and surgical treatment options. Dtsch. Arztebl. Int. 2011, 108, 669-677. [CrossRef] [PubMed]

5. Johnstone, B.; Hering, T.M.; Caplan, A.I.; Goldberg, V.M.; Yoo, J.U. In vitro chondrogenesis of bone marrow-derived mesenchymal progenitor cells. Exp. Cell Res. 1998, 238, 265-272. [CrossRef]

6. Mackay, A.M.; Beck, S.C.; Murphy, J.M.; Barry, F.P.; Chichester, C.O.; Pittenger, M.F. Chondrogenic differentiation of cultured human mesenchymal stem cells from marrow. Tissue Eng. 1998, 4, 415-428. [CrossRef] [PubMed]

7. Orth, P.; Rey-Rico, A.; Venkatesan, J.K.; Madry, H.; Cucchiarini, M. Current perspectives in stem cell research for knee cartilage repair. Stem Cells Cloning 2014, 7, 1-17. [CrossRef]

8. Evans, C.H.; Huard, J. Gene therapy approaches to regenerating the musculoskeletal system. Nat. Rev. Rheumatol. 2015, 11, 234-242. [CrossRef]

9. Frisch, J.; KVenkatesan, J.; Rey-Rico, A.; Madry, H.; Cucchiarini, M. Current progress in stem cell-based gene therapy for articular cartilage repair. Curr. Stem Cell Res. Ther. 2015, 10, 121-131. [CrossRef]

10. Cucchiarini, M. Human gene therapy: Novel approaches to improve the current gene delivery systems. Discov. Med. 2016, 21, 495-506.

11. Pagnotto, M.R.; Wang, Z.; Karpie, J.C.; Ferretti, M.; Xiao, X.; Chu, C.R. Adeno-associated viral gene transfer of transforming growth factor- $\beta 1$ to human mesenchymal stem cells improves cartilage repair. Gene Ther. 2007, 14, 804-813. [CrossRef] [PubMed]

12. Stender, S.; Murphy, M.; O’Brien, T.; Stengaard, C.; Ulrich-Vinther, M.; Soballe, K.; Barry, F. Adeno-associated viral vector transduction of human mesenchymal stem cells. Eur. Cells Mater. 2007, 13, 93-99. [CrossRef]

13. Cucchiarini, M.; Ekici, M.; Schetting, S.; Kohn, D.; Madry, H. Metabolic activities and chondrogenic differentiation of human mesenchymal stem cells following recombinant adeno-associated virus-mediated gene transfer and overexpression of fibroblast growth factor 2. Tissue Eng. Part A 2011, 17, 1921-1933. [CrossRef] [PubMed]

14. Venkatesan, J.K.; Ekici, M.; Madry, H.; Schmitt, G.; Kohn, D.; Cucchiarini, M. SOX9 gene transfer via safe, stable, replication-defective recombinant adeno-associated virus vectors as a novel, powerful tool to enhance the chondrogenic potential of human mesenchymal stem cells. Stem Cell Res. Ther. 2012, 3, 22-36. [CrossRef] [PubMed]

15. Frisch, J.; Venkatesan, J.K.; Rey-Rico, A.; Schmitt, G.; Madry, H.; Cucchiarini, M. Determination of the chondrogenic differentiation processes in human bone marrow-derived mesenchymal stem cells genetically modified to overexpress transforming growth factor- $\beta$ via recombinant adeno-associated viral vectors. Hum. Gene Ther. 2014, 25, 1050-1060. [CrossRef] [PubMed]

16. Frisch, J.; Venkatesan, J.K.; Rey-Rico, A.; Schmitt, G.; Madry, H.; Cucchiarini, M. Influence of insulin-like growth factor I overexpression via recombinant adeno-associated vector gene transfer upon the biological activities and differentiation potential of human bone marrow-derived mesenchymal stem cells. Stem Cell Res. Ther. 2014, 5, 103-114. [CrossRef] [PubMed]

17. Tao, K.; Frisch, J.; Rey-Rico, A.; Venkatesan, J.K.; Schmitt, G.; Madry, H.; Lin, J.; Cucchiarini, M. Co-overexpression of TGF- $\beta$ and SOX9 via rAAV gene transfer modulates the metabolic and chondrogenic activities of human bone marrow-derived mesenchymal stem cells. Stem Cell Res. Ther. 2016, 7, 20-31. [CrossRef]

18. Morscheid, S.; Rey-Rico, A.; Schmitt, G.; Madry, H.; Cucchiarini, M.; Venkatesan, J.K. Therapeutic effects of rAAV-mediated concomitant gene transfer and overexpression of TGF- $\beta$ and IGF-I on the chondrogenesis of human bone marrow-derived mesenchymal stem cells. Int. J. Mol. Sci. 2019. [CrossRef] [PubMed] 
19. Rey-Rico, A.; Venkatesan, J.K.; Sohier, J.; Moroni, L.; Cucchiarini, M.; Madry, H. Adapted chondrogenic differentiation of human mesenchymal stem cells via controlled release of TGF- $\beta$ from poly(ethylene oxide)-terephtalate/poly(butylene terephtalate) multiblock scaffolds. J. Biomed. Mater. Res. A 2015, 103, 371-383. [CrossRef]

20. De Vries-van Melle, M.L.; Mandl, E.W.; Kops, N.; Koevoet, W.J.; Verhaar, J.A.; van Osch, G.J. An osteochondral culture model to study mechanism involved in articular cartilage repair. Tissue Eng. Part C 2012, 18, 45-53. [CrossRef]

21. Rey-Rico, A.; Frisch, J.; Venkatesan, J.K.; Schmitt, G.; Rial-Hermida, I.; Taboada, P.; Concheiro, A.; Madry, H.; Alvarez-Lorenzo, C.; Cucchiarini, M. PEO-PPO-PEO carriers for rAAV-mediated transduction of human articular chondrocytes in vitro and in a human osteochondral defect model. ACS Appl. Mater. Interfaces 2016, 8, 20600-20613. [CrossRef] [PubMed]

22. Samulski, R.J.; Chang, L.S.; Shenk, T. A recombinant plasmid from which an infectious adeno-associated virus genome can be excised in vitro and its use to study viral replication. J. Virol. 1987, 61, 3096-3101. [PubMed]

23. Samulski, R.J.; Chang, L.S.; Shenk, T. Helper-free stocks of recombinant adeno associated viruses: Normal integration does not require viral gene expression. J. Virol. 1989, 63, 3822-3828. [PubMed]

24. Venkatesan, J.K.; Rey-Rico, A.; Schmitt, G.; Wezel, A.; Madry, H.; Cucchiarini, M. rAAV-mediated overexpression of TGF- $\beta$ stably restructures human osteoarthritic articular cartilage in situ. J. Transl. Med. 2013, 11, 211-224. [CrossRef] [PubMed]

25. Shi, S.; Mercer, S.; Eckert, G.J.; Trippel, S.B. Growth factor stimulation of growth factors in articular chondrocytes. J. Biol. Chem. 2009, 284, 6697-6704. [CrossRef] [PubMed]

26. Goldring, M.B.; Fukuo, K.; Birkhead, J.R.; Dudek, E.; Sandell, L.J. Transcriptional suppression by interleukin- $\alpha$ and interferon-gamma of type II collagen gene expression in chondrocytes. J. Cell. Biochem. 1994, 54, 85-99. [CrossRef] [PubMed]

27. Calcedo, R.; Wilson, J.M. Humoral immune response to AAV. Front. Immunol. 2013, 4, 341. [CrossRef] [PubMed]

28. Cucchiarini, M.; Madry, H.; Ma, C.; Thurn, T.; Zurakowski, D.; Menger, M.D.; Kohn, D.; Trippel, S.B.; Terwilliger, E.F. Improved tissue repair in articular cartilage defects in vivo by rAAV-mediated overexpression of human fibroblast growth factor 2. Mol. Ther. 2005, 12, 229-238. [CrossRef]

29. Osborn, K.D.; Trippel, S.B.; Mankin, H.J. Growth factor stimulation of adult articualr cartilage. J. Orthop. Res. 1989, 7, 35-42. [CrossRef] [PubMed]

30. Khan, I.M.; Gilbert, S.J.; Singhrao, S.K.; Duance, V.C.; Archer, C.W. Cartilage integration: Evaluation of the reasons for failure of integration during cartilage repair. A review. Eur. Cells Mater. 2008, 16, 26-39. [CrossRef]

31. Bal, B.S.; Rahaman, M.N.; Jayabalan, P.; Kuroki, K.; Cockrell, M.K.; Yao, J.Q.; Cook, J.L. In vivo outcomes of tissue-engineered osteochondral grafts. J. Biomed. Mater. Res. B Appl. Biomater. 2010, 93, 164-174. [CrossRef]

32. Goldring, M.B.; Tsuchimochi, K.; Ijiri, K. The control of chondrogenesis. J. Cell. Biochem. 2006, 97, 33-44. [CrossRef]

33. Cucchiarini, M.; Madry, H. Overexpression of human IGF-I via direct rAAV-mediated gene transfer improves the early repair of articular cartilage defects in vivo. Gene Ther. 2014, 21, 811-819. [CrossRef]

34. Cucchiarini, M.; Asen, A.K.; Goebel, L.; Venkatesan, J.K.; Schmitt, G.; Zurakowski, D.; Menger, M.D.; Laschke, M.W.; Madry, H. Effects of TGF- $\beta$ overexpression via rAAV gene transfer on the early repair processes in an osteochondral defect model in minipigs. Am. J. Sports Med. 2018, 46, 1987-1996. [CrossRef]

(C) 2019 by the authors. Licensee MDPI, Basel, Switzerland. This article is an open access article distributed under the terms and conditions of the Creative Commons Attribution (CC BY) license (http://creativecommons.org/licenses/by/4.0/). 